\title{
Testing functional theory of life values with students living in residential care institutions
}

\author{
Cátia Marques ${ }^{1}$, Ana Daniela Silva ${ }^{1} \&$ Maria do Céu Taveira ${ }^{1}$ \\ ${ }^{1}$ School of Psychology, University of Minho, Braga, Portugal
}

\begin{abstract}
The Functional Theory of Life Values can constitute a useful theoretical basis for evaluating and promoting the psychosocial development of young people. This study aimed to analyze the adequacy of this theory with students living in residential care institutions. We tested two main hypotheses: a content hypothesis, using a six-dimensional values model (excitement, promotion, existence, supra-personal, interactive, normative), and a structure hypothesis, which represents values in two space dimensions (type of orientation guiding actions goals; and type of motivator expressing needs). Participants included 230 Portuguese youths, 121 boys (52.6\%) and 109 girls (47.4\%) aged 12 to 25 years old $(M=16.1, S D=$ 2.03). A demographic questionnaire and the Basic Values Survey were completed. Confirmatory factor analysis and confirmatory multidimensional scaling were used to test the content and structure hypotheses. The results support both hypotheses and provide empirical support to the theory with this population.
\end{abstract}

\section{Keywords: Values; foster care; youths; confirmatory factor analysis.}

Teste da teoria funcionalista dos valores humanos com estudantes em acolhimento residencial: A teoria Funcionalista dos Valores de Vida pode constituir uma base teórica útil para avaliar e promover o desenvolvimento psicossocial dos jovens. Este estudo teve como objetivo analisar a adequação desta teoria com estudantes em acolhimento residencial. Testaram-se duas hipóteses principais: uma hipótese de conteúdo, utilizando um modelo de valores tridimensionais (experimentação, realização, existência, suprapessoal, interativo, normativo) e uma hipótese de estrutura, que representa valores em duas dimensões espaciais (tipo de orientação guiando à obtenção de objetivos; e tipo de motivador expressando necessidades). Os participantes incluíram 230 portugueses, 121 rapazes (52,6\%) e 109 raparigas $(47,4 \%)$, entre os 12 e os 25 anos $(M=16,1, D P=2,03)$. Foram preenchidos dados demográficos e o Questionário dos Valores Básicos de Vida. As hipóteses de conteúdo e estrutura foram testadas através de análise fatorial confirmatória e escalonamento multidimensional. Os resultados suportam as hipóteses e fornecem suporte empírico à teoria com esta população.

Palavras-chave: Valores; jovens em acolhimento; análise fatorial confirmatória.

Values are an important dimension of self-construction during adolescence and youth, with a significant impact on their perceptions, goals, attitudes, and behaviors, regarding interpersonal and social relationships and career development (e.g., Bardi \& Goodwin, 2011). Acknowledging the relevance of this construct, several scholars have been trying to understand and explain vulnerable life trajectories based on human values (e.g., Álvaro et al., 2015; Formiga, 2006, 2010; Formiga, Aguiar, \& Omar, 2008; Formiga \& Gouveia, 2005; Tulvist \& Gutman, 2003), the role that values play in the experience of discrimination in vulnerable groups (Espinosa, Clemente, \& Uña, 2016), and youth career choices (e.g., Bojovic, Vasilijević, \& Sudzilovski, 2015).

One of the values theories that has been helpful to study vulnerable groups is the Functional Theory of Values (Gouveia, 1998, 2003, 2013). This theory integrates previous theoretical values models proposed by Rokeach (1973), Inglehart (1977), and Schwartz (1992) and allows us to overcome the insufficiency of the dichotomous conception of individualism-collectivism in the field of human values (Gouveia, Andrade, Milfont, Queiroga, \& Santos, 2003) by presenting a more comprehensive view of values structure, including pro-social, central, and personal orientations or goals.

Youths in residential care settings are considered in the literature as a vulnerable group (e.g., González-Garcia, Lázaro-Visa, Santos, Del Valle, \& Bravo, 2017), since they are at risk to develop academic underachievement, dropout of school, and participate in deviant behaviors (Silva, Coelho, \& Taveira, 2017). The literature also suggests that youths in residential care settings show self-blaming statements,

${ }^{1}$ Address for correspondence: School of Psychology, University of Minho, Braga, Portugal. E-mail: ceuta@psi.uminho.pt 
feelings of incompetence, low self-esteem, and perceptions of uncertainty concerning to the future (e.g., Magalhães \& Lopes, 2011).

It is essential to pay attention to the life career development of this specific group of the population in situations of greater vulnerability. The FTV can be helpful to conceptualize and study the values priorities of youths and help them in redefining their future taking these priorities into consideration.

The FTV has been tested in Brazil (Fischer, Milfont, \& Gouveia, 2011; Gouveia, Milfont, Fischer, \& Coelho, 2009; Gouveia, Milfont, \& Guerra, 2014; Gouveia, Milfont, Vione, \& Santos, 2015), and in twelve other countries (Ardila, Gouveia, \& Medeiros, 2012; Gouveia et al., 2010a; Marques, Silva, Taveira, \& Gouveia, 2016; Medeiros, 2011), based on the use of the Basic Values Survey (BVS; Gouveia, 2003). The literature has been emphasizing the importance of having a congruence between behaviors, actions, and values. Authors such as Hayes, Luoma, Bond, Masuda, and Lillis (2006) affirm that once the individuals experience the world more directly, their behaviors are more flexible, and thus, their actions more consistent with their values. This study aims to offer complementary evidence for the validity and reliability of the FTV among Portuguese students, by testing the dimensional and structural models of FTV in a group of students living in residential care institutions, in order to decide on the use and utility of the FTV model and measure with this group of the population.

\section{The Functional Theory of Values}

The study of value's structure emerged decades ago and has become a main topic of focus in psychology research (e.g., Gouveia, 1998; Rokeach, 1973; Schwartz, 2005). According to Gouveia's functional theory, values are understood as guiding actions, as expressions of one's needs, and as pre-conditions for satisfying those needs (Gouveia et al., 2003). Based on this theory (e.g., Gouveia, 2003; Gouveia et al., 2015), values are organized along two main functional dimensions: type of orientation regarding goals and type of motivator expressing needs. The goals orientation function includes three dimensions: personal, central, and social goals. The motivational function includes two dimensions: thriving (or more idealistic) needs and survival (or more materialistic) needs. These five dimensions interact with each other to originate six value subfunctions or categories: interactive, normative, suprapersonal, existence, excitement, and promotion.

The interactive subfunction includes values of a social goal orientation and express thriving needs, such as affection, belonging, and support. Individuals guided by these values pay special attention to social contacts and affective relationships. The normative subfunction covers values also directed to a social goal orientation, such as tradition, obedience, and religiosity. These values cognitively represent the need for security and control, as well as the pre-conditions to satisfy basic needs (institutional and social demands according to Schwartz, 1992). Normative values focus on social rules with a survival or more materialistic guiding principle.

The suprapersonal subfunction includes values of a central goal orientation and express thriving needs, such as knowledge, maturity, and beauty. Individuals guided by these values prioritize abstract ideas, as compared to the importance given to concrete and material topics. The existence subfunction also reflects a central goal orientation but expresses needs, such as health, survival, and personal stability. Individuals guided by these values are focused on basic conditions for biological and psychological survival.

The excitement subfunction concerns the values of a personal goal orientation and expresses thriving needs, such as sexuality, pleasure, and emotion. Individuals guided by these values are willing and open to change and innovation in social organization, and at the same time are less willing to comply with social rules. The promotion subfunction also includes values of a personal goal orientation but expresses survival needs, such as success, prestige, and power. Individuals guided by promotion values tend to be efficient, task-oriented, successful, and competitive (Gouveia et al., 2014).

Youths who prioritize personal values are more likely to present deviant behaviors, whereas youths who prioritize social values, maintenance of tradition, and social norms are more concerned with the collective good and less likely to engage in delinquent behaviors (Formiga, 2010). Hence, the investment in values that aim at individualism might contribute to increased deviant behaviors among youths, while the investment in values which stimulate behavior into social collectivist norms might contribute to a decrease of antisocial and criminal behaviors (Formiga, 2006; Formiga \& Gouveia, 2005). On one hand, individuals presenting excitement values are more likely deviate from social standards. On the other hand, youths who prioritize normative as well as interactive and suprapersonal values are motivated to adopt social standards, present socially positive behaviors more often, and protect themselves against disruptive behaviors (Santos, 2008). As youths become more committed to adapt to different standards of behavior, their ability to internalize prevalent social values and standards in the social groups to which they belong will likewise increase. However, the cultural changes that have last 
occurred in our societies prompt an individualistic spirit among young people and stimulate them to prioritize interests and personal needs, which might increase the likelihood of disruptive behaviors (Santos, 2008).

This study intends to advance the Functional Theory, while testing and promoting the study of values with vulnerable populations to understand how they could construct their life projects. Particularly, this study aims to validate the FTV (Gouveia, 1998) with a sample of students living in residential care institutions in Portugal. In this sense, we test two main hypotheses: a content hypothesis, using a six-dimensional values model (excitement, promotion, existence, suprapersonal, interactive, normative), and a structure hypothesis, which represents values in two space dimensions (type of orientation guiding actions goals and type of motivator expressing needs). In fact, youth presenting vulnerable life trajectories are at risk for deviant behaviors (Stein, 2006), and their psychosocial problems have gained attention in Psychology fields. Empirical evidence has suggested that this vulnerable group faces barriers in decision-making during transitional periods (e.g., Marques et al., 2016; Silva \& Ribeiro, 2012; Stein, 2006). Residential care youths have also been shown to present weaker selfexploration beliefs and lower satisfaction with the information derived from the career exploration process than peers living with their families (Marques, 2017). It seems, therefore, important to study these individuals' values to further help them construct and integrate their professional intentions and life projects, both interpersonally and socially, and consequently contribute to a fairer and egalitarian society.

\section{METHOD}

\section{Participants}

Two hundred and thirty youths participated in this study, comprised of 121 boys (52.6\%) and 109 girls (47.4\%) living in residential care institutions in Portugal ${ }^{2}$, aged 12 to 25 years old $(M=16.1, S D=2.03)$. Eighty-one percent (14 institutions) are from the north of the country, 11\% (one institution) from the center, and 8\% (two institutions) from the islands (Madeira and Azores). At the time of this study, 44.8\% of the participants were attending elementary school, $30.4 \%$ were in high school, and $3 \%$ were in higher education.

\section{Measure}

The participants completed demographic questions (e.g., sex, age, school year, and name of institution), and the Basic Values Survey (BVS; Gouveia, 2003). This self-report instrument includes a total of 18 items, corresponding to 18 values equally distributed among the six aforementioned subfunctions. For each item, two descriptors are shown (e.g., Tradition: follow the social norms of your country, respect the traditions of their society; Affection: to have a deep and enduring affectionate relationship, to have somebody to share successes and failures). Participants used a seven-point response scale, ranging from 1 "totally unimportant" to 7 "of the utmost importance," to evaluate the importance of each value as a guiding priority in their lives. There was evidence of factorial validity and internal consistency reliability of this instrument in the Brazil context (e.g., Gouveia et al., 2015), in other 11 countries (Medeiros, 2011), and also in the Portuguese context, with non-foster youth samples (Marques et al., 2016).

\section{Procedure}

After obtaining informed consent from the institutions' boards, students were invited to participate in the study. The study was part of a large-scale national research program on students living in residential care institutions in Portugal, which was approved by the Portuguese Foundation for Science and Technology (FCT/SFRH/BPD/64078/2009). The present study was approved by the Research Ethics Committee of the University of Minho. Once the ethical requirements were fulfilled, anonymity was ensured. After obtaining the consensus of the direction of the institutions, all participants signed an informed consent form. According to the CASA 2014 report, there were 3021 youths older than 12 years old living in residential care settings in Portugal in that time. The sample of this study corresponds to $7.8 \%$ of the students living in residential care institutions. We contacted 236 institutions. Of these contacted institutions, $16(6.8 \%)$ agreed to collaborate with the project. The response ratio in 11 of these institutions were $100 \%$. In the remaining ones, the response ratio was on average $69.3 \%$. A demographic questionnaire and the BVS were administered to the youth by a trained research assistant. Although the

\footnotetext{
2 Residential care institutions host children and youths who are vulnerable and at risk of developing physical and mental problems if they remain in their families. Children and youths in these situations are evaluated by a technical team, and, when justifiable, they are removed from their natural environments until their families have the necessary conditions to receive them again or when they reach the age of 21 .
} 
surveys were answered in a collective context, in class, responses were given individually. The aim of the study was clarified to all participants. Participants were informed that the collaboration with this study was voluntary. Confidentiality of responses, properly treated collectively and statistically, was assured. Approximately 15 minutes were required for youths to complete the survey. The inclusion criteria for participants in the study were: to be able and willing to participate and to be a student older than 12 years old living in a residential care institution. Students that did not have these characteristics were considered within the exclusion criteria.

\section{Data Analysis}

The statistical data analyses were performed with version 24 of the Statistical Package for Social Sciences (IBM SPSS Statistics 24). There were no missing data across the items of the measure. The assumptions of multivariate normality of sampling distribution and absence of outliers were previously checked. Descriptive statistics (frequency, mean, and standard deviation), internal consistency (homogeneity and Cronbach's alpha) of values subfunctions, and confirmatory Multidimensional scaling (MDS algorithm Proxscal) were calculated. Before creating a distance matrix, the values were transformed into $\mathrm{Z}$ scores. The Tucker's Phi coefficient was used as a measure of model fit, with values of .90 or higher being indicative of good fit (van de Vijver \& Leung, 1997).

The Analysis of Moment Structures (AMOS), version 22 for Windows, was used to conduct a Confirmatory Factor Analyses (CFA). Due to the non-normality of the sampling distribution, the Maximum Likelihood (ML) estimation method with bootstrapping was used. We aimed to determine the relative adjustment of the theorized model (original model with six subfunctions) against three alternative models including a different number of factors: bifactorial (the values were distributed according the type of motivator: materialistic and idealist), trifactorial (the values were organized according the type of orientation: personal, social, and central), and pentafactorial (values of existence and suprapersonal subfunctions) (Gouveia et al., 2011). To test the fit of the FTV six factor and alternative models to the data, the following indicators and criteria were considered: relative/normed chi-square statistic, with values around 2.0 considered as satisfactory (Tabachnick \& Fidell, 2007); the Goodness-of-Fit-Index (GFI) and the Comparative Fit Index (CFI), with values of 0.90 or greater generally accepted as indicating wellfitting models (Tabachnick \& Fidell, 2007); and the Root-Mean Square Error of Approximation (RMSEA), with a value close to 0.06 or a stringent upper limit of 0.07 considered as a good result (Steiger, 2007).

\section{RESULTS}

Descriptive results of the values subfunctions are presented in Table 1. The descriptive results suggested higher existence and suprapersonal values and lower normative and promotion values. In what concerns internal consistency, the alpha coefficients are .59 for social values, .60 for personal values, and .73 for central values.

Table 1. Values of students in foster care residential institutions: Descriptive statistics.

\begin{tabular}{lcc}
\hline Subfunctions & $\boldsymbol{M}$ & $\boldsymbol{S D}$ \\
\hline Excitement & 4.96 & 1.13 \\
Promotion & 4.86 & 1.10 \\
Existence & 5.92 & 1.12 \\
Suprapersonal & 5.46 & 1.13 \\
Interactive & 5.27 & 1.14 \\
Normative & 4.69 & 1.17 \\
\hline
\end{tabular}

In this study, the alpha coefficient for excitement and normative subfunctions is . 35 , for promotion subfunction it is .38 , for interactive subfunction it is .53, and for suprapersonanal and existence subfunctions they are .54 and .62, respectively. In previous studies with the BVS (e.g., Gouveia et al., 2014), the alpha coefficients ranged from .53 for interactive subfunction to .60 for normative subfunction (with an average of alfa values of .56). Then, the main hypotheses of the Functional Theory of Values were tested.

The CFA results testing the original model against the five alternative ones are presented in Table 2. 
Table 2. Values of students living in residential institutions: Testing the functional theory content hypothesis.

\begin{tabular}{lccccc}
\hline Model & $\boldsymbol{x}^{\mathbf{2}}$ & $\boldsymbol{d} \boldsymbol{f}$ & GFI & CFI & RMSEA \\
\hline Six factor & 339.99 & 118 & .859 & .775 & $.091(.079-.102)$ \\
Five factor & 383.33 & 125 & .842 & .738 & $.095(.084-.106)$ \\
Three factor & 484.10 & 132 & .810 & .643 & $.168(.159-.177)$ \\
Two factor & 406.34 & 134 & .831 & .724 & $094(.084-.105)$ \\
One factor & 406.70 & 135 & .831 & .724 & $0.91(.083-.104)$ \\
\hline
\end{tabular}

The six factor model showed the best adjustment results compared with the alternative ones, although the values of the indices of fit considered are not completely satisfactory. The relative/normed chi-square statistic decreased as the number of factors tested in the model increased. On the other hand, the values of GFI and CFI indices augmented as the number of factors tested in the model increased. The MDS confirmatory results (algorithm proxscal) obtained by the SPSS (version 22) are represented in Figure 1.

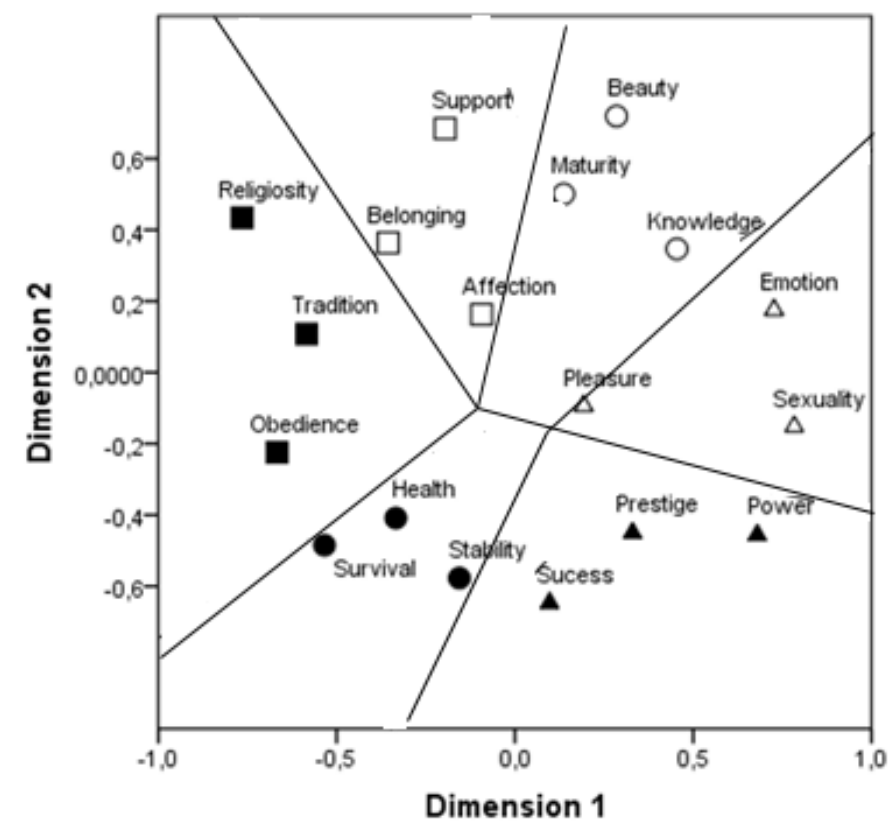

Figure 1. Spatial representation of values.

As it can be seen in Figure 1, the six evaluative theorized subfunctions were represented in a bidimensional space, showing a satisfactory adjustment (Tucker's Phi $=.93$ ). Materialistic (filled icons) and idealistic values (unfilled icons) were represented in two different regions of space. Moreover, the central values (circles) were among the social (squares) and individual values (triangles). These results support the structure hypothesis.

\section{DISCUSSION AND CONCLUSIONS}

The main goal of this study was to assess the adequacy of the Functional Theory of Values, developed by Gouveia (Gouveia, 1998, 2003, 2013) with a sample of Portuguese students living in residential care institutions, testing the content and structural hypotheses of the model. These theoretical hypotheses were supported by CFA with this sample. The results indicate that six sub functions (interactive, normative, suprapersonal, existence, excitement, and promotion) fit satisfactorily the data. Even with the age range of the participants of the study being large (from 12 to 25 years old), the absence of outliers gives us confidence regarding the conducted analysis and obtained results. In fact, only six students were more than 20 years old. In this sample, students of different ages seem to interpret the questionnaire in a similar way, as well as present a similar profile regarding their values priorities. These results are consistent with the results of other studies in which it is concluded that age has a limited influence on values (e.g., Schwartz, 2005). Although the FTV theory has been previously tested with Brazilian physicians (Gouveia et al., 2014), Brazilian university students (Gouveia et al., 2015), and with students 
from diverse other countries (e.g., Gouveia et al., 2010a; Marques et al., 2016), this study provides the first empirical test of the three-by-two FTV framework with Portuguese students living in residential care institutions. According to the FTV authors, the model of six factors should provide the most appropriate adjustment to the data. Our results also suggest that models with more factors are more suitable than models with fewer factors, whereby the model of six factors presented the best fit to the data. The structure hypothesis postulates that the central values are located between personal and social values, and are located on opposite sides of the bi-dimensional space. This hypothesis was also supported by confirmatory MDS analysis. In this study, the BVS consistency results are low, although similar results have been found with the same and other values measures (e.g., Gouveia et al., 2014; Lönnqvist, Jasinskaja-Lahti, \& Verkasalo, 2011; Schwartz, 2005), indicating moderate internal consistent evidence for the BVS. These results can be explained by the reduced number of items that are included on the analysis (three items per subfunction). At the same time, a reduced number of items can be an asset for research proposes since the questionnaire is short and it is easily filled.

Overall, the results support the content and structure hypotheses of the Functional Theory of Values. These results are consistent with additional studies conducted with other samples that similarly corroborate this theory. It is, therefore, possible to conclude that the values of students in residential care settings can be described by the Functional Theory of Values. In this study, participants presented higher scores on existence (health, survival, and personal stability) and suprapersonal (knowledge, maturity, and beauty) values, which constitute the central goals and correspond to materialistic and idealist needs of the values' model. In turn, participants scored lower in normative (tradition, obedience, and religiosity) and promotion (success, prestige, and power) values, which correspond to materialistic needs. In this way, the participants of this study seem to be focused on basic conditions for biological and psychological survival (existence) and to prioritize abstract ideas against to concrete and material topics (suprapersonal values). According to Santos (2008), individuals who are characterized by suprapersonal values are motivated to adopt social standards and protect themselves against disruptive behaviors. These results give us important clues to continue working and promoting suprapersonal values within youth in residential care settings and help to protect themselves against deviant behaviors. Regarding Formiga and Gouveia (2005), promoting values that stimulate the behavior into social collectivist norms instead of individualistic values can contribute to the diminution of deviant behaviors. These kinds of values could be stimulating, for example, with group dynamics through dilemmas.

Despite the contribution of this study, we relied on a reduced sample size due to the challenges faced in data collection with this population. A replication of this study must consider this, and, if possible, conduct efforts to enlarge the sample of students in residential care institutions. Another limitation concerns the use of a single type of self-reporting instrument. This method of data collection has some disadvantages, since the participants can distort the reported content, giving answers which differ from what would be real values (Kohlsdorf \& Junior, 2009). In future research, another possibility to handle this limitation is to obtain an independent measure of social desirability and use that either to omit responses that are 'high' in social desirability or partial out variance that is correlated with social desirability (Marques et al., 2016).

Nonetheless, it is worth mentioning that this is the first study testing the FTV and the Basic Values Survey with students living in residential care institutions. Our results confirm the suitability of the theory and measure, thus affording the possibility to continue developing studies of this nature focused on human values. For example, future studies could test the functional theory in a wider cultural sample, as well as test other hypotheses derived from the theory, such as the compatibility and congruence hypotheses (Gouveia, 2013). Based on this study, it seems also important to plan intervention programs that acknowledge the vulnerable condition of these population and their values priorities. Particularly, this study suggests that practitioners may be trained in and rely on the functionalist model to work with this population.

At the intervention level, through the implementation of career development programs, these students could reflect about the various life roles, including the student and worker roles, and about the values guiding priorities and thoughts, feelings and actions in each of those life roles. These kinds of interventions can help students in designing their future and in the development of curiosity and exploration of possible selves. Curiosity can help them to know more about themselves and about career opportunities, to be more able to adapt to life challenges, to have information to make decisions, to imagine themselves in the future, and to avoid dissatisfaction and difficulties on career decision-making related, for example, with lack of information or inconsistent information on their values priorities. 


\section{REFERENCES}

Álvaro, J., Oliveira, T., Torres, A., Pereira, C., Garrido, A., \& Canino, L. (2015). The role of values in attitudes towards violence: Discrimination against Moroccans and Romanian gypsies in Spain. Spanish Journal of Psychology, 18, 1-12. http://dx.doi.org/10.1017/sjp.2015.65

Ardila, R., Gouveia, V., \& Medeiros, E. (2012). Human values of Colombian people: Evidence for the functionalist theory of values. Revista Lationoamericana de Psicología, 44(3), 105-117. https://doi.org/10.1177/0022022110396916

Bardi, A., \& Goodwin, R. (2011). The dual route to value change: Individual processes and cultural $\begin{array}{llll}\text { moderators. Journal of Cross-Cultural Psychology, } & 42, & \text { 271-287. }\end{array}$ http://dx.doi.org/10.1177/0022022110396916

Bojovic, Z., Vasilijević, D., \& Sudzilovski, D. (2015). Values and value orientations of students, future primary school teachers and preschool teachers. Croatian Journal of Education, 17, 11-35. http://dx.doi.org/10.15516/cje.v17i0.1339

CASA (2014). Relatório de caracterização anual da situação de acolhimento das crianças e jovens. Departamento de Desenvolvimento Social e Programas/ Unidade de Infância e Juventude. Lisboa: Instituto da Segurança Social.

Espinosa, P., Clemente, M., \& Uña, O. (2016). Motivational values, parental influences and the experience of discrimination among Romanian and Moroccan young immigrants in Spain. Spanish Journal of Psychology, 19, 1-11. http://dx.doi.org/10.1017/sjp.2016.79

Fischer, R., Milfont, T., \& Gouveia, V. (2011). Does social context affect value structures? Testing the within country stability of value structures with a functional theory of values. Journal of Cross-Cultural Psychology, 42, 253-270. http://dx.doi.org/10.1177/0022022110396888

Formiga, N. (2006). Valores humanos e condutas delinquentes: as bases normativas da conduta antisocial e delitiva em jovens brasileiros. Psicologia para América Latina, (7) Recuperado em 23 de maio de 2017, de http://pepsic.bvsalud.org/scielo.php?script=sci_arttext\&pid=S1870$350 \times 2006000300005 \& \operatorname{lng}=p t \& \operatorname{lng}=p t$

Formiga, N. (2010). Valores humanos e condutas desviantes: sua acurácia correlacional em jovens brasileiros. Cadernos de Pesquisa Interdisciplinar em Ciências Humanas, 98, 409-425. http://dx.doi.org/10.5007/1984-8951.2010v11n98p409

Formiga, N., Aguiar, M., \& Omar, A. (2008). Busca de sensação e condutas anti-sociais e delitivas em jovens. Psicologia Ciência e Profissão, 28(4), 668-681.

Formiga, N., \& Gouveia, V. (2005). Valores humanos e condutas anti-sociais e delitivas. Psicologia: Teoria e Prática, 7(2), 134-170.

González-Garcia, C., Lázaro-Visa, S., Santos, I., Del Valle, J., \& Bravo, A. (2017). School functioning of a particularly vulnerable group: Children and young people in residential child care. Frontiers in Psychology, 8, 1-12. http://dx.doi.org/10.3389/fpsyg.2017.01116

Gouveia, V. (1998). La naturaleza de los valores descriptores del individualismo e del colectivismo: una comparación intra e intercultural (Unpublished doctoral dissertation). Universidade Complutense de Madrid, Espanha.

Gouveia, V. (2003). A natureza motivacional dos valores humanos: evidências acerca de uma nova tipologia. Estudos de Psicologia, 8(3), 431-443.

Gouveia, V. (2013). Teoria funcional dos valores humanos: fundamentos, aplicações e perspectivas. São Paulo: Casa do Psicólogo.

Gouveia, V., Andrade M., Milfont, T., Queiroga, F., \& Santos, W. (2003). Dimensões normativas do individualismo e coletivismo: é suficiente a dicotomia pessoal vs. social? Psicologia: Reflexão e Crítica, 16(2), 223-234.

Gouveia, V., Milfont, T., Fischer, R., \& Coelho, J. (2009). Teoria funcionalista dos valores humanos: aplicações para organizações. Revista de Administração Mackenzie, 10, 34-59. http://dx.doi.org/10.1590/S1678-69712009000300004

Gouveia, V., Milfont, T., \& Guerra, V. (2014). Functional theory of human values: Testing its content and structure hypotheses. Personality and Individual Differences, 60, 41-47. http://dx.doi.org/10.1016/j.paid.2013.12.012

Gouveia, V., Milfont, T., Vione, K., \& Santos, (2015). Guiding actions and expressing needs: On the psychological functions of values. Psykhe, 24, 1-14. http://dx.doi.org/10.7764/psykhe.24.2.884

Gouveia, V., Santos, W., Milfont, T., Fischer, R., Clemente, M., \& Espinosa, P. (2010a). Teoría funcionalista de los valores humanos en España: comprobación de las hipótesis de contenido y estructura. Interamerican Journal of Psychology, 44(2), 203-214. 
Gouveia, V., Sousa, D., Fonseca, P., Gouveia, R., Gomes, A., \& Rodrigues, R. (2010b). Valores, metas de realização e desempenho acadêmico: proposta de modelo explicativo. Revista Semestral da Associação Brasileira de Psicologia Escolar e Educacional, 14(2), 323-331.

Hayes, S.C., Luoma, J.B., Bond, F.W., Masuda, A., \& Lillis, J. (2006). Acceptance and commitment therapy: Model, processes and outcomes. Behaviour Research and Therapy, 44. 1-25. http://dx.doi.org/10.1016/j.brat.2005.06.006

Inglehart, R. (1977). The silent revolution: Changing values and political styles among Western publics. Princeton, NJ: Princeton University Press.

Kohlsdorf, M., \& Junior, A. L. (2009). O autorrelato na pesquisa em psicologia da saúde: desafios metodológicos. Psicologia Argumento (Curitiba), 27(57), 131-139.

Lönnqvist, J.E., Jasinskaja-Lahti, I., \& Verkasalo, M. (2011). Personal values before and after migration: A longitudinal case study on value change in Ingrian-Finnish migrants. Social Psychological and Personality Science, 2, 584-591. http://dx.doi.org/10.1177/1948550611402362

Marques, C. (2017). Valores básicos de vida e reflexividade ética na carreira em jovens. Saarbrucken, Alemanha: Novas Edições Académicas.

Magalhães, E., \& Lopes, J. (2011). Auto-conceito em adolescentes institucionalizadas: Um estudo exploratório. Revista Psicologia, XXV(2), 163-180.

Marques, C., Silva, A. D., Taveira, M.C., \& Gouveia, V. (2016). Functional theory of values: Results of a confirmatory factor analysis with Portuguese youths. Interamerican Journal of Psychology, 50(3), 392-401.

Medeiros, E. D. (2011). Teoria Funcionalista dos Valores Humanos: testando sua adequação intra e interculturalmente (Unpublished doctoral dissertation). Department of Psychology, Federal University of Paraíba, João Pessoa, Brazil.

Silva, A.D., Coelho, P., \& Taveira, M.C. (2017). Effectiveness of a career intervention for empowerment of institutionalized youth. Vulnerable Children and Youth Studies, 12, 171-181. http://dx.doi.org/10.1080/17450128.2017.1282070

Rokeach, M. (1973). The nature of human values. New York, NY: Free Press.

Santos, W. S. (2008). Explicando comportamentos socialmente desviantes: uma análise do compromisso convencional e afiliação social (Unpublished doctoral dissertation). Department of Psychology, Federal University of Paraíba, João Pessoa, Brazil.

Schwartz, S. (1992). Universals in the content and structure of values: Theoretical advances and empirical tests in 20 countries. In M. P. Zanna (Eds.), Advances in experimental social psychology (pp. 1-65). New York: Academic Press.

Schwartz, S. H. (2005). Robustness and fruitfulness of a theory of universals in individual human values. In A. Tamayo \& J. B. Porto (Eds.), Valores e trabalho (pp. 21-55). Petrópolis, Brazil: Vozes.

Silva, A. D., \& Ribeiro, M. A. (2012). Learning, achievement and career of institutionalized youths: Portraits of the Portuguese and Brazilian realities. In M. C. Taveira, J. C. Pinto, \& A. D. Silva (Eds.), Learning, Achievement and career development (pp. 27-53). Braga: APDC Edições.

Steiger, J.H. (2007). Understanding the limitations of global fit assessment in structural equation modeling. Personality and Individual Differences, 42, 893-98. http://dx.doi.org/10.1016/j.paid.2006.09.017

Stein, M. (2006). Research review: Young people leaving care. Child and Family Social Work, 11, 273-279. http://dx.doi.org/10.1111/j.1365-2206.2006.00439.x

Tabachnick, B.G., \& Fidell, L.S. (2007). Using Multivariate Statistics (5th ed.). New York: Allyn and Bacon.

Tulvist, T., \& Gutman, P. (2003). A comparison of value preferences and attitudes toward collectivism of institution-reared and home-reared teenagers. European Journal of Psychology of Education, 18, 3342. http://dx.doi.org/10.1007/BF03173602

van de Vijver, F. J. R., \& Leung, K. (1997). Methods and data analysis for cross-cultural research. Thousand Oaks, CA: Sage Publications.

Historial do artigo

Recebido 21/07/2017

Aceite $\quad 01 / 03 / 2018$

Publicado $\quad 05 / 2018$ 